\title{
MANIFESTATION FORMS OF INTENSE MUSCLE EFFORTS AND FACTORS INFLUENCING THE DEVELOPMENT OF STRENGTH MOTOR CAPACITY
}

\author{
Robert STĂNCIULESCU \\ rstanciulescu@armyacademy.ro \\ “NICOLAE BĂLCESCU” LAND FORCES ACADEMY, SIBIU, ROMANIA
}

\begin{abstract}
:
Physical training, a component of the sports training aims, besides the development of morphological and functional indexes of the body and mastering a rich system of motor skills and capabilities, the development and improvement of the basic motor qualities at high performance parameters. Most motor activities require the endowment of athletes with possibilities to make intensive efforts in a very short period of time. Therefore, the issue that is focusing on the study of this field is very important for achieving the targeted performance.
\end{abstract}

\section{KEYWORDS:}

Effort, parameters, motor skills, capacity, training

\section{Introduction}

Lately, more and more specialists highlight the crucial role, central we could say, that force has in obtaining better performances. Most physical acts specific to sports disciplines require fitting athletes with opportunities to perform work of intensity as high as possible in a very short time and with maximum efficiency. Motor skills that enable man to overcome resistance or oppose it by an intense muscular effort, muscle strength has major effects in obtaining performance. The development, strengthening and improvement of abilities and motor skills specific to various sports study disciplines and the development of the other motor skills required depend very much on its value. Of course, there are a number of factors that, besides the need to use the most appropriate methodological procedures to develop this motor quality, they influence the amount of muscle force. Depending on them, the most competitive and appropriate ways to develop this motor quality can be chosen. A very important element is the number of fibres involved in 
the contraction. Between their number and the value of the strength there is a connection of direct proportionality, i.e. the higher the number of muscle fibres, the greater the value of the strength (Tudor, 1999). Of great importance is also the thickness of the muscle involved in the activity. Therefore, the bigger the front cross section of a muscle force is, the greater the strength developed. In same time there are other elements that can be taken into consideration. Thus, of great importance is the quality of metabolic processes and energy substances which can be found in the muscle groups involved in contraction. The level of development of the other motor qualities and especially of those directly involved in the motor action is also of special importance.

\section{Strength - Manifestation Forms}

Many specialists who have studied the motor quality of strength, failed to formulate the exact definition, because a clear and precise definition of strength is only possible if taking into account its various forms. Specialists' definitions do not differ, as with the other motor qualities, but in terms of the terminology used. Therefore:

$>$ V.M. Zatiorski (1968). defines strength as the human's ability to overcome an external resistance or to act against it through muscular effort;

$>$ A. Demeter (1981) says that strength is the ability of the neuromuscular system to overcome resistance by muscle contraction;

$>N$. Alexe says that strength is the human's ability to overcome external resistance measured in $\mathrm{kg}$ using weightlifting dynamometry;

$>$ R. Manno (1996) defines strength as the motor ability which enables man to overcome resistance, to oppose it, by an intense effort of the muscles.

The human body manifests its strengths by making efforts in which mechanical work is present or not. Exercise performed is for overcoming, maintaining or compliance, depending on the resistance that has to be overcome. It is necessary to distinguish between strength and muscle power. Strength means overcoming resistance without being conditioned by time and power refers to the mechanical work per time unit.

The factors that influence the muscle strength are diverse and wide. The key factors of strength are divided, for teaching purposes, into two categories: central factors and peripheral factors.

Central factors refer to:

$>$ The activity of the nerves involved in making the voluntary or involuntary actions;

The stimuli that once they reach the psychic-sensory systems are transformed into sensations. They induce into the motor areas focal points of excitations at different levels of C.N.S. (central nervous system) on whose extent and frequency of orders' release depends the degree of mobility of the motor units that conditions the strength;

$>$ Intramuscular coordination, conducted by cortical and subcortical motor centres, as facilitators of the movement;

Adjusting the muscle tonus which has implications on the increase of the strength. Usually, the rest tonus with the lowest values leads to the increase of the force of contraction.

Peripheral factors influence in particular the maximum strength, but also the other forms of strength (Mitra \& Mogos, 1980). These relate to:

$>$ the diameter of the muscle, which depends on the thickness of the muscle fibres that form it, the amount of sarcoplasm, the number of myofibers, the amount of connective and fat tissue;

$>$ muscle hypertrophy, which is the increase of each muscle fibre's diameter. Depending on the intensity, frequency and duration of the stimuli, muscle fibre structure will evolve in favour of strength or resistance. Hettinger, in 1960, states that for $1 \mathrm{~cm}^{2}$ of section corresponds $6 \mathrm{~kg}$. force;

$>$ the amount of energy resources of the muscle and the enzymes that foster 
burning, such as adenosine triphosphate acid and phosphocreatine, which by reaction immediately releases a large amount of energy necessary to muscle strength;

$>$ the volume of the muscle with impact on damaging the muscle strength;

$>$ the structure of the muscle - the high percentage of phasic fibres which have a higher diameter with increased phosgene supplies favours the anaerobic processes and, since they are mobilized by high frequency impulses, they favour the development of strength;

$>$ the length of the muscle fibres and the angle of action.

Strength also depends on other factors, such as:

- angular value of the working segments;

- motivation;

- ability to focus attention on the task;

- duration of the muscle contraction;

- state of functionality of the support segments, ligaments and joints;

- development of the other motor qualities;

- age;

- gender;

- continuity of the training process;

- initial level from which the training begins;

- quality of the training's forms of organization.

Regarding the manifestation of strength, it takes place in a different way, depending on the characteristic of each sport and the performed motor actions. The analyses undertaken in this direction have highlighted many forms, grouped according to the criteria used, as follows: mass:

according to the involved body

- local strength, which refers to the strength of certain muscle groups used by the distinctiveness of the sports branch or the sports test;
- general strength, a form which refers to the strength of the entire muscle system.

$>$ according to the activity in which the strength is required, we have the general strength and the specific strength;

according to the type of the muscle contraction:

- static strength, characterised by the fact that it is carried out exclusively by isometric contractions, without changes of the muscle fibres' sizes which are used in carrying out that effort;

- dynamic strength, also known as isotonic strength, occurs when, by contraction, the size of the muscle fibres changes, either increasing, or decreasing. If a shortening of the muscle fibres occurs, the dynamic strength is overcoming type (miometric diet), and if an elongation of muscle fibres occurs and the force acts in the direction of the movement, the force is dynamic concession type (plyometric diet);

- mixed force, a type in which both static and dynamic contractions are met.

In reality, strength is never manifested purely, but in combination with the other motor qualities and therefore, we have:

$>$ strength under speed also called explosive strength which is the ability to manifest high values of strength in the shortest time unit;

strength under resistance, which is the body's ability to make an effort of force for a longer period of time.

According to the body weight, there are two categories of strength: absolute strength and relative strength.

D. Harre (1973) makes the following classification of strength:

$>$ maximal strength, which is the largest strength that the neuromuscular system produces in a voluntary contraction;

strength/speed which is characterised by the ability that the 
neuromuscular system has to overcome resistance at the highest speed of contraction;

$>$ force of resistance, which is the ability that allows the body to oppose fatigue by an exercise in which force is combined with duration.

\section{Methodical Processes of Developing Muscle Strength}

Depending on the manifestations forms of strength a number of specific development means and methods can be used. The main methodical processes of strength development are:

\section{The circuit procedure:}

This aims to develop the main muscle groups. Most specialists appreciate that, if well organized, this type of training provides the best results of all processes. In this method it is advisable that:

- exercises do not require high indices of ability;

- the difficulty of the exercises increase progressively;

- exercises do not have a high degree of difficulty.

There are many ways of circuit training, the vast majority being for developing general and special strength (Cârstea, 1999). Thus: the repetition circuit; intensive circuit; long duration circuit; extensive circuit or long, short or medium circuit are only a few of the many existing forms. There are several steps that must be respected when it is used:

- knowing the principles that direct activity in this type of work-out and adapting to demands; athletes;

- knowing the level of training of

- periodic review of results.

Using exercises with maximum efficiency:

Power-Training Method:

It is a method which seeks the development of strength together with the development of speed. It is a highly precise method because it observes strictly the origin indications and the manner in which the effort's scaling is done. The main types of exercises used are:

- weightlifting exercises;

- exercises with stuffed balls;

- acrobatic exercises.

There are a number of elements that need to be taken into account in its use:

- size of the load; increasing the number of repetitions, increasing the execution speed.

\section{The isometric contraction}

It aims the development of strength by pushing a static resistance, situation where muscle length is not modified. It involves the production of tension on the muscle which is in action. It can be carried out from various positions. It should be noted that this method will alternate with the isotonic method.

\section{Weight lifting method;}

This is a method through which the development of maximum strength is achieved. It is characterised by the fact that in the spotlight there is the intensity of the effort, namely the increase of the load (Teodorescu, 1984). There are at least four procedures to increase the load:

- continuous increase of the load;

- stepped-increase of the load;

- continuous increase and decrease;

- wave load.

In order to achieve efficiency by applying this method it is necessary to take into account the principle of progress and the characteristics of the effort undergone by the athletes' body.

\section{Conclusions}

A motor quality of vital importance for achieving performance in all sports, strength has been and will remain in the attention of specialists who are constantly seeking for the most sophisticated means 
and ways to get the maximum effects in programs to develop motor capacities.

Of course, regardless of the methods used in specific activities for developing strength the following guidelines must be considered:

- Proper training of the body for the effort that the body is put through;

- Practicing activities that would reduce stress and boredom and that would enhance motivation and progress;

- A hard day of practice should be followed by an easy day of training;

- The work load for every training session must exceed the normal demands of the body to get effects;

- Low energy consumption and maximum efficiency;

- Using breaks to restore the body's capacities.

Systematically capitalizing the indications mentioned before and using the most adequate methods and means to develop the motor capacity creates the prerequisites for obtaining increased performances.

\section{REFERENCES}

Cârstea, Gh. (1999). Educaţia fizică - fundamente teoretice şi metodice, Bucureşti: Casa de editură Petru Maior.

Demeter, A. (1981). Bazele fiziologice şi biochimice ale calităţilor motrice, Bucureşti: Sport-Turism.

Harre, D., et al. (1973). Teoria antrenamentului sportiv, Bucureşti: Stadion.

Manno, R. (1996). Bazele teoretice ale antrenamentului sportiv, Bucureşti: C.C.P.S. Turism.

Mitra, Gh. \& Mogoş, Al. (1980). Metodica educaţiei fizice şcolare, Bucureşti: Sport-

Niculescu, M. (2003). Metodologia cercetării ştiinţifice în educaţie fizică şi sport Vol. 1 \& 2, Bucureşti: BREN.

Teodorescu, L. (1984). Orientări şi tendinţe în teoria şi metodologia antrenamentului modern, Revista de educaţie fizică şi sport, nr. 4.

Tudor, V. (1999), Capacităţile condiţionale şi coordinative - componente ale capacităţii motrice, Bucureşti: Coresi.

Zatiorski, V.M. (1968). Calităţile fizice ale sportivului (traducere), Bucureşti: Editura C.N.F.S. 